\title{
Hidden treasures: the Paris Observatory
}

\author{
Giovanni Domenico Cassini helped to create an institution that pinpointed Neptune, showed that \\ light had a finite speed - and even mapped France, explains Alison Abbott.
}

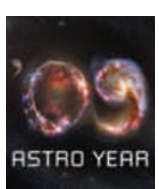

Giovanni Domenico Cassini was a mathematical genius with finely tuned social skills, a quick wit and a habit of enthralling powerful political figures. In 1650, when Cassini was just 25, the Pope appointed him professor of astronomy at his university in Bologna, Italy. He gave Cassini the fattest salary there, to the chagrin of his more established colleagues, and called on him to help resolve some of the highest issues of state. These varied from escorting Sweden's Queen Christina to Rome when she wished to convert to Catholicism - a brief romance apparently sparked between them during the long journey - to determining the direction of water flow in the Apennine mountain range that bordered the papal states, to designing papal fortifications.

Meanwhile, France's Louis XIV, the Sun King, was hatching grandiose plans for his country - among them an academy of sciences and arts and an observatory for experimental sciences, particularly astronomy. $\mathrm{He}$ commissioned his minister, Jean-Baptiste Colbert, to scour Europe for the best scientists and artists. In 1668, Colbert made Cassini a financial offer he could not refuse. With the indulgence of the Pope, who was keen to maintain good relations with the French king during a time of political and religious tensions, Cassini set off immediately for Paris. There he joined the fledgling academy and served as royal adviser on the building of the observatory. It was supposed to be a temporary visit. The university in Bologna griped about the Pope's insistence to continue paying him, even when it became clear Cassini wouldn't return. The Pope turned a deaf ear.

Louis XIV loved Cassini from the beginning. Although not formally the first director of the observatory, which was completed in 1682, he assumed the role in practice. Just five years after he arrived, the king bestowed French citizenship on him.

His privileged relationship with Louis XIV was as much a source of annoyance to some Parisian colleagues as his relationship to the Pope had been in Bologna. But Cassini, with his large personality and outstanding scientific achievements - ranging from the discovery of a gap in the rings of Saturn to unveiling the structure of snowflakes - was

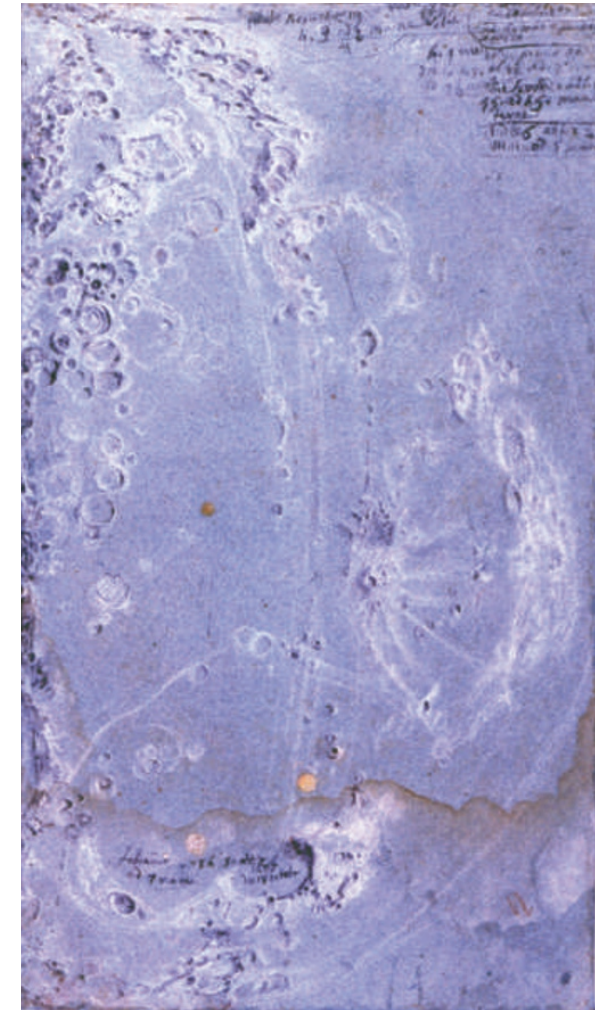

Cassini relied on an artist to depict his Moon views.

a major influence on the development of French science.

The king was reportedly less pleased with Cassini's great expedition in the early 1670s. Together with Jean-Felix Picard and Philippe de La Hire, he remapped France using astronomy, ingeniously exploiting Galileo's 1610 discovery of four satellites of Jupiter. They used the eclipses of these satellites as time reference points to measure longitude differences between locations on the coasts of France. The resultant map showed France to be narrower than previously thought, with the kingdom losing $20 \%$ of its surface area. Poor recompense, the king said, for the solicitude he had shown his astronomers.

The observatory was built in the countryside, some way from the centre of Paris. Louis XIV had fondly imagined it would be the academy's meeting place, but the scientists found that it took too long to get there and continued to meet in town. Today it has been swallowed up by the city, sheltered from the roar of traffic behind walls that encircle generous gardens. Visitors will appreciate why Cassini argued, unsuccessfully, with the architects in 1668: the space is hardly optimal for scientific endeavour. It looks more like a palace than a place of work.

But it resounds with history. Vast knowledge was accumulated here, from the 1676 discovery that the speed of light was finite, to the accurate pinpointing of Neptune's position using the observed perturbations of the orbit of Uranus. The high-ceilinged, cavernous rooms are now ideal for displaying the massive wood-and-brass astronomical instruments that form much of the collection of the observatory's museum, created in 1878. Although by then some of the oldest instruments had been lost during expeditions, more than 500 objects remain, including the telescope of Léon Foucault - more famous for his pendulum and the first to use the thin, silver-plated mirrors found in modern telescopes.

The library, founded in 1785 , has also benefited from major acquisitions. During and just after the French Revolution in the 1790 s, Cassini's great-grandson donated his forebear's library and extensive records of astronomical observations, as well as those of the three Cassini generations who subsequently directed the observatory - their dynasty lasted for more than a century. Then, the eighteenth-century astronomer JosephNicolas Delisle sold the library a vast number of astronomy manuscripts that he had assiduously collected during his decades of travels around Europe and Russia. Most valuable are the 16 boxes of manuscripts by the great Polish astronomer Johannes Hevelius, including all his correspondence.

The library's greatest treasures are perhaps the original drawings of the surface of the Moon (as pictured) made by Cassini's engraver, who sat beside the astronomer as he made his observations. For all his attributes, Cassini was not a gifted artist. These shaded pastel drawings, made under his guidance and annotated in his own hand, have rarely been seen. Those fortunate enough to examine them will experience a rush - such a direct emotional connection with history is rare, and powerful. Alison Abbott is Nature's senior European correspondent.

See http://tinyurl.com/6yxa68 for details. See Editorial, page 7, and www.nature.com/astro09. 